\title{
MENINGKATKAN KETERAMPILAN PROSES SISWA KELAS X.5 SMAN 4 BARABAI MELALUI PENERAPAN MODEL INKUIRI TERBIMBING PADA KONSEP EKOSISTEM
}

\author{
Norhasanah \\ SMAN 4 Barabai \\ Email: sanahmadina@gmail.com
}

\begin{abstract}
ABSTRAK
Pembelajaran biologi di SMAN 4 Barabai masih menekankan konsep-konsep yang terdapat di dalam buku dan kurang dikaitkan dengan lingkungan belajar siswa terutama pada konsep yang berhubungan dengan lingkungan. Model inkuiri terbimbing untuk membangun keterampilan proses siswa belum intensif digunakan, oleh karena itu dilakukan penelitian tindakan kelas untuk meningkatkan keterampilan proses siswa. Subjek penelitian siswa kelas X.5 SMAN 4 Barabai berjumlah 32 orang siswa. Penelitian tindakan kelas dilaksanakan dua siklus, setiap siklus dilakukan dua kali pertemuan digunakan dalam penelitian ini. Data hasil penelitian diperoleh dari hasil observasi terhadap keterampilan proses siswa. Data diolah dengan dijumlahkan untuk mendapatkan rata-rata keterampilan siswa. Hasil penelitian menunjukkan skor rata-rata keterampilan proses siswa kelas X.5 SMAN 4 mengalami peningkatan. Siklus I diperoleh skor rata-rata 2,11 dengan kategori cukup baik, sedangkan pada siklus II diperoleh skor rata-rata 3,05 dengan kategori baik. Keterampilan proses merumuskan masalah atau pertanyaan, merumuskan hipotesis atau jawaban sementara, merumuskan prosedur kerja dalam melakukan pengamatan dan melakukan penyelidikan melalui pengamatan adalah rata-rata baik. Sedangkan menganalisis hasil pengamatan dan membuat kesimpulan berdasarkan hasil pengamatan adalah ratarata cukup baik.
\end{abstract}

Kata kunci: keterampilan proses, model inkuiri terbimbing, konsep ekosistem.

\begin{abstract}
Teaching of Biology at SMAN 4 Barabai is still emphasizing on the concepts stated in the books and less associated to the students' learning environment, especially on the concepts related to the environment. Guided inquiry model to build the process skills of the students have not been intensively implemented, therefore there is a need to conduct action research to improve the skills of the students. The research subject is the X.5 grade students of SMAN 4 Barabai constisted of 32 students. The classroom action research is conducted in two cycles, each cycle consits of two meetings in this study. The data were obtained from the observation of the process skills of students. The data is processed by summerising method to obtain the average score of the students' skills. The results showed that an average score of process skills from X.5 grade SMAN 4 students has increased. In cycle I, the obtained average score is 2.11 with a good category, while in the cycle II, the obtained average score is 3.05 in both categories. The average scores of process skills on formulating a problem or question, formulating hypotheses or answering, formulating working procedures in observation and investigation through observation are categorized as good.
\end{abstract}

Keywords: process skills, guided inquiry model, the concept of the ecosystem. 


\section{PENDAHULUAN}

Keberhasilan pendidikan ditentukan berbagai faktor. Salah satu faktor yang mempengaruhi mutu pendidikan adalah tersedianya perangkat pembelajaran. Guru sebagai agen pembelajar harus mampu menyajikan proses pembelajaran secara kontekstual dengan melibatkan langsung peran serta siswa secara aktif. Sebagian siswa belajar dengan baik apabila mereka mendapat kesempatan berinteraksi dengan benda-benda nyata melalui aktivitas penyelidikan yang akan membantu siswa memperdalam pemahaman suatu konsep (Nur, 2000; Kariani, 2015).

Berdasarkan informasi dan observasi awal yang dilakukan peneliti, pembelajaran biologi khususnya di SMAN 4 Barabai lebih menekankan segi kognitif sedangkan keterampilan proses masih jauh dari harapan. Siswa masih sulit menerapkan konsep biologi yang diperoleh di kelas untuk memecahkan masalah kehidupan sehari-hari. .

Ditinjau dari segi proses sains, pembelajaran biologi memiliki berbagai aspek untuk membangun keterampilan proses. Misalnya: (a) keterampilan menyusun laporan secara sistematis, (b) menjelaskan hasil percobaan atau pengamatan, (c) cara mendiskusikan hasil percobaan, (d) cara membaca grafik atau tabel, dan (e) keterampilan mengajukan pertanyaan. Jika aspek-aspek proses ilmiah tersebut disusun dalam suatu urutan tertentu dan digunakan untuk memecahkan suatu permasalahan yang dihadapi, maka rangkaian proses ilmiah itu menurut Towle (1989) menjadi suatu metode ilmiah.

Menurut Bryce, dkk. (1990) keterampilan proses IPA mencakup keterampilan dasar sebagai kemampuan yang terendah, kemudian diikuti dengan keterampilan proses. Sebagai keterampilan tertinggi adalah keterampilan investigasi. Keterampilan proses merupakan bagian esensial dari hasil pembelajaran yang diharapkan siswasiswa yang belajar Sains (termasuk biologi). Sushkin (2001) menjelaskan kontruktivisme berisi pengajaran yang menekankan pada penemuan, pemecahan masalah, dan mengutamakan pada keterampilan proses.

Inkuiri sebagai model merupakan salah satu pembelajaran yang dapat diadaptasikan dengan kemampuan siswa, dapat membangun struktur kognitif, dan dapat memotivasi siswa untuk berpikir kritis. Hamalik (2004) menjelaskan pendekatan inkuiri adalah suatu strategi yang berpusat pada siswa. Pendekatan inkuiri meliputi keterampilan proses bertanya dan mencari tahu jawaban terhadap pertanyaan ilmiah yang diajukannya.

Pembelajaran biologi yang dikembangkan dari lingkungan diharapkan dapat mendorong dan membantu siswa dalam pembelajaran. Penggunaan inkuiri terbimbing dirasa tepat untuk maksud ini. Menurut Kuhlthau \& Todd (2007) siswa dibimbing oleh guru dalam membangun pengetahuan dan pemahaman mengenai objek dan persoalan sains. Pembelajaran dengan inkuiri terbimbing dapat meningkatkan respon siswa, namun belum signifikan berpengaruh pada peningkatan penguasaan konsep biologi (Soesanti, 2005). Hidayat (2005) menemukan hasil yang agak berbeda, ialah adanya pengaruh yang signifikan metode inkuiri terbimbing terhadap pemahaman konsep siswa, kemampuan afektif, dan psikomotor siswa. 
Berdasarkan penelitian Sukamti (2004) metode inkuiri terbimbing memungkinkan siswa terlibat secara aktif menggunakan proses mentalnya untuk menemukan beberapa konsep dan prinsip materi yang sedang dipelajari. Murtiani (2008) melaporkan penggunaan pendekatan inkuiri dapat meningkatkan hasil belajar dan aktivitas siswa. Sejauh ini model inkuiri terbimbing, khususnya untuk membangun keterampilan siswa melakukan keterampilan proses di SMAN 4 Barabai, belum intensif digunakan. Oleh karena itu perlu dilakukan penelitian mengenai bagaimana meningkatan keterampilan proses siswa kelas X.5 SMAN 4 Barabai melalui penerapan model inkuiri terbimbing pada konsep ekosistem.

\section{METODE PENELITIAN}

Penelitian tindakan kelas dilaksanakan dua siklus, setiap siklus terdiri atas dua kali pertemuan. Subjek penelitian siswa kelas X.5 SMAN 4 Barabai berjumlah 32 orang siswa. Dipilih siswa kelas X.5 ini, dengan pertimbangan sebagai berikut: (1) dipilihnya kelas X.5, diasumsikan telah mulai matang dalam belajar. (2) Kelas X.5 SMAN 4 Barabai sudah menerapkan Kurikulum Tingkat Satuan Pelajaran yang mana dalam kurikulum tersebut identik dengan pembelajaran Kooperatif. (3) Kelas X.5 memiliki daya serap yang tinggi, namun pada umumnya keterampilan melakukan kerja ilmiahnya masih rendah.

Penelitian dilaksanakan di SMAN 4 Barabai, Jalan Surapati Banua Jingah Kecamatan Barabai Kabupaten Hulu Sungai Tengah. Penelitian dilaksanakan pada Desember 2015, Januari dan Februari 2016.
Instrumen penelitian ini berupa perangkat pembelajaran yang terdiri dari silabus, RPP, LKS, materi ajar, dan evaluasi seperti pada lampiran 1 . Perangkat pembelajaran dilengkapi dengan sebagai berikut: 1) lembar observasi keterampilan proses siswa dalam kegiatan inkuiri terbimbing, 2) lembar observasi aktivitas guru dalam pengelolaan pembelajaran, 3) lembar observasi perilaku berkarakter dan keterampilan sosial siswa, 4) lembar kerja siswa (hasil belajar proses), 5) tes (hasil belajar kognitif), dan 6) angket respon siswa.

Prosedur Penelitian Tindakan Kelas ini direncanakan 2 siklus dimana masingmasing siklus terdiri 2 kali pertemuan, diharapkan hasilnya akan dapat dilihat secara objektif. Untuk dapat melihat kesalahan yang dibuat siswa dalam memahami konsep ekosistem serta presentasi kebenaran dalam mengerjakan soal maka diberikan pre test sebagai evaluasi awal, evaluasi awal dilakukan untuk mengetahui tindakan tepat yang diberikan dalam rangka meminimalkan kesalahan tersebut, selanjutnya diberikan post test untuk mengetahui keberhasilan siswa setelah dilakukan pembelajaran dengan model inkuiri terbimbing.

Sumber data utama diperoleh dari keterampilan proses siswa dalam kegiatan inkuiri terbimbing. Jenis data yang didapatkan adalah keterampilan proses siswa dalam kegiatan inkuiri terbimbing. Kemampuan siswa dapat dilihat dari beberapa kali melaksanakan tes dan observasi kegiatan yaitu kemajuan dari hasil observasi dan tes awal dengan membandingkan dengan tes akhir, serta melihat perbandingan dari hasil yang diperoleh dari setiap siklus pembelajaran. 
Hasil penelitian berupa hasil observasi terhadap keterampilan proses siswa dalam kegiatan inkuiri terbimbing. Data keterampilan proses siswa dalam kegiatan inkuiri terbimbing dianalisis secara deskriptif dengan menggunakan kategorikal yakni sangat baik $(4-4,99)$, baik (3- 3,99), cukup baik (2 - 2,99), kurang (1-1,99) (Borich, 1994).

Indikator keberhasilan penelitian (akhir siklus 2) sesuai dengan per- timbangan yang digunakan pada refleksi akhir siklus 1 . Penelitian ini dikatakan berhasil optimal apabila keterampilan proses siswa dalam kegiatan inkuiri telah menunjukkan kenaikan dari siklus 1 ke siklus 2 .

\section{HASIL DAN PEMBAHASAN}

Hasil penelitian siklus I adalah ratarata keterampilan proses disajikan pada Tabel 1.

Tabel 1. Keterampilan Proses Siswa dalam Kegiatan Inkuiri Terbimbing pada Siklus I

\begin{tabular}{|c|c|c|c|c|c|c|c|}
\hline \multirow{2}{*}{ No. } & \multirow[t]{2}{*}{ Jenis Aktivitas } & \multicolumn{4}{|c|}{ Siklus I } & \multirow{2}{*}{$\begin{array}{c}\text { Skor } \\
\text { Rata-rata }\end{array}$} & \multirow{2}{*}{ Kategori } \\
\hline & & 1 & 2 & 3 & 4 & & \\
\hline 1. & $\begin{array}{l}\text { Merumuskan masalah atau } \\
\text { pertanyaan }\end{array}$ & 2,50 & 2,00 & 1,75 & 2,00 & 2,06 & $\begin{array}{l}\text { Cukup } \\
\text { Baik }\end{array}$ \\
\hline 2. & $\begin{array}{l}\text { Merumuskan hipotesis atau } \\
\text { jawaban sementara }\end{array}$ & 2,25 & 1,75 & 1,75 & 2,50 & 2,06 & $\begin{array}{l}\text { Cukup } \\
\text { Baik }\end{array}$ \\
\hline 3. & $\begin{array}{l}\text { Merumuskan prosedur kerja } \\
\text { dalam melakukan pengamatan }\end{array}$ & 2,25 & 1,50 & 1,75 & 2,50 & 2,00 & $\begin{array}{l}\text { Cukup } \\
\text { Baik }\end{array}$ \\
\hline 4. & $\begin{array}{l}\text { Melakukan penyelidikan } \\
\text { melalui pengamatan }\end{array}$ & 2,75 & 2,50 & 2,00 & 2,50 & 2,44 & $\begin{array}{l}\text { Cukup } \\
\text { Baik }\end{array}$ \\
\hline 5. & Men ganal isis hasil pengamatan & 2,50 & 1,75 & 1,50 & 2,00 & 1,94 & Kurang \\
\hline 6. & $\begin{array}{l}\text { Membuat kesimpulan } \\
\text { berdasarkan pengamatan }\end{array}$ & 2,25 & 1,75 & 2,50 & 2,00 & 2,13 & $\begin{array}{l}\text { Cukup } \\
\text { Baik }\end{array}$ \\
\hline
\end{tabular}

Keterangan: $(1-1,99)=$ Kurang, $(2-2,99)=$ Cukup Baik, $(3-3,99)=$ Baik, $(4-4,99)=$ Sangat Baik

Nilai Siswa 1 (Linda), Siswa 2 (Rizki), Siswa 3 (Sabirin). Siswa 4 (Zaini)

Keterampilan proses siswa pada Tabel rekomendasi dilaksanakan pembelajaran 1 rata-rata cukup baik, sedangkan kemampuan menganalisis hasil penelitian masih kurang, ini menjadi salah satu

pada siklus II.

Hasil penelitian pada siklus II disajikan pada Tabel 2.

Tabel 2. Keterampilan Proses Siswa dalam Kegiatan Inkuiri Terbimbing pada Siklus II

\begin{tabular}{|c|c|c|c|c|c|c|c|}
\hline \multirow{2}{*}{ No. } & \multirow{2}{*}{ Jenis Aktivitas } & \multicolumn{4}{|c|}{ Siklus II } & \multirow{2}{*}{$\begin{array}{c}\text { Skor } \\
\text { Rata-rata }\end{array}$} & \multirow{2}{*}{ Kategori } \\
\hline & & 1 & 2 & 3 & 4 & & \\
\hline 1. & $\begin{array}{l}\text { Merumuskan masalah atau } \\
\text { pertanyaan }\end{array}$ & 3,75 & 3,00 & 3,00 & 3,25 & 3,25 & Baik \\
\hline 2. & $\begin{array}{l}\text { Merumuskan hipotesis atau } \\
\text { jawaban sementara }\end{array}$ & 3,50 & 2,75 & 3,25 & 3,50 & 3,25 & Baik \\
\hline
\end{tabular}




\begin{tabular}{|c|c|c|c|c|c|c|c|}
\hline \multirow{2}{*}{ No. } & \multirow[t]{2}{*}{ Jenis Aktivitas } & \multicolumn{4}{|c|}{ Siklus II } & \multirow{2}{*}{$\begin{array}{l}\text { Skor } \\
\text { Rata-rata }\end{array}$} & \multirow{2}{*}{ Kategori } \\
\hline & & 1 & 2 & 3 & 4 & & \\
\hline 3. & $\begin{array}{l}\text { Merumuskan prosedur kerja } \\
\text { dalam melakukan pengamatan }\end{array}$ & 3,50 & 3,00 & 2,75 & 3,00 & 3,06 & Baik \\
\hline 4. & $\begin{array}{l}\text { Melakukan penyelidikan } \\
\text { melalui pengamatan }\end{array}$ & 3,75 & 3,00 & 3,00 & 3,50 & 3,31 & Baik \\
\hline 5. & Menganal isis hasil pengamatan & 3,00 & 2,00 & 2,75 & 2,75 & 2,63 & $\begin{array}{c}\text { Cukup } \\
\text { Baik }\end{array}$ \\
\hline 6. & $\begin{array}{l}\text { Membuat kesimpulan } \\
\text { berdasarkan pengamatan }\end{array}$ & 3,00 & 2,75 & 2,75 & 2,75 & 2,81 & $\begin{array}{c}\text { Cukup } \\
\text { Baik }\end{array}$ \\
\hline
\end{tabular}

Keterangan: $(1-1,99)=$ Kurang, $(2-2,99)=$ Cukup Baik, $(3-3,99)=$ Baik, $(4-4,99)=$ Sangat Baik Nilai Siswa 1 (Linda), Siswa 2 (Rizki), Siswa 3 (Sabirin). Siswa 4 (Zaini)

Tabel 3 menunjukkan siswa masih kesulitan dalm melaksanakan kegiatan menganalisis hasil pengamatan dan membuat kesimpulan. Meskipun masih dijumpai ketidak-berhasilan memperbaiki keterapilan proses, namun penelitian ini diakhiri pada siklus II.

Deskripsi keterampilan proses siklus I dan siklus II disajikan pada Tabel 3.

Tabel 3. Keterampilan Proses Siswa Siklus I dan Siklus II

\begin{tabular}{|c|l|c|c|}
\hline \multirow{2}{*}{ No. Jenis Aktivitas } & \multicolumn{2}{c|}{ Skor Rata-rata } \\
\cline { 3 - 4 } & & Siklus I & Siklus II \\
\hline 1. & Merumuskan masalah atau pertanyaan & 2,06 & 3,25 \\
\hline 2. & Merumuskan hipotesis atau jawaban sementara & 2,06 & 3,25 \\
\hline 3. & $\begin{array}{l}\text { Merumuskan prosedur kerja dalam melakukan } \\
\text { pengamatan }\end{array}$ & 2,00 & 3,06 \\
\hline 4. & Melakukan penyelidikan melalui pengamatan & 2,44 & 3,31 \\
\hline 5. & Menganalisis hasil pengamatan & 1,94 & 2,63 \\
\hline 6. & Membuat kesimpulan berdasarkan pen gamatan & 2,13 & 2,81 \\
\hline & Skor Rata-Rata & $\mathbf{2 , 1 1}$ & $\mathbf{3 , 0 5}$ \\
\hline
\end{tabular}

Keterangan:(1-1,99) = Kurang, $(2-2,99)=$ Cukup Baik,(3- 3,99) = Baik,(4- 4,99) = Sangat Baik

Sekalipun secara kuantitatif terjadi peningkatan, namun bila dicermati lebih lanjut hanya 4 keterampilan proses yang berhasil ditingkatkan. Sedangkan sisanya belum ada perubahan, yakni dua keterampilan proses terakhir.

Berdasarkan rumusan tujuan yang dikemukakan sebelumnya pembelajaran inkuiri dapat meningkatkan keterampilan proses (merumuskan masalah, merumuskan hipotesis, merumuskan prosedur kerja, dan melaksanakan pengamatan) namun belum berhasil meningkatkan keterampilan proses menganalisis hasil penelitian dan membuat kesimpulan.

Keterampilan proses siswa dalam merumuskan masalah dapat ditingkatkan, hal ini sesuai dengan penelitian sebelumnya (Markawi, 2015). Masalah atau pertanyaan yang mereka rumuskan 
muncul secara logis dari hasil pengamatan, merupakan paparan pengamatan, dibuat dengan baik, menuntun ke arah pengamatan selanjutnya, merupakan tafsiran hasil pengamatan, Menurut Sanjaya (2012) keterampilan proses dalam merumuskan masalah merupakan langkah membawa siswa pada suatu persoalan yang mengandung tekateki. Persoalan yang disajikan adalah persoalan yang menantang siswa untuk berpikir memecahkan teka teki itu. Dikatakan teka teki dalam rumusan masalah yang ingin dikaji disebabkan masalah itu tentu ada jawabannya dan siswa didorong untuk mencari jawaban yang tepat. Proses mencari jawaban itulah yang sangat penting dalam strategi inkuiri, oleh sebab itu melalui proses tersebut siswa akan memperoleh pengalaman yang sangat berharga sebagai upaya mengembangkan mental melalui proses berpikir. Dengan demikian, teka teki yang menjadi masalah dalam berinkuiri adalah teka teki yang mengandung konsep yang jelas yang harus dicari dan ditemukan, seperti penemuan secara langsung pada ekosistem sawah.

Keterampilan proses siswa dalam merumuskan hipotesis juga mengalami peningkatan, artinya siswa sudah mulai terampil dengan menggunakan kalimat pernyataan dan rumusan yang baik, sehingga siswa sudah mampu menghasilkan prediksi yang masuk akal dan dapat digunakan untuk merancang suatu percobaan. Menurut Sanjaya (2012) keterampilan proses siswa dalam merumuskan hipotesis dari suatu permasalahan yang sedang dikaji. Sebagai jawaban sementara, hipotesis perlu diuji kebenarannya. Kemampuan atau potensi individu untuk berpikir pada dasarnya sudah dimiliki sejak individu itu lahir. Potensi berpikir itu dimulai dari kemampuan setiap individu untuk menebak atau mengira-ngira (berhipotesis) dari suatu permasalahan. Manakala individu dapat membuktikan tebakannya, maka ia akan sampai pada posisi yang bisa mendorong untuk berpikir lebih lanjut. Oleh sebab itu, potensi untuk mengembangkan kemampuan menebak pada setiap individu harus dibina. Salah satu cara yang dapat dilakukan guru untuk mengembangkan kemampuan menebak (berhipotesis) pada setiap anak adalah dengan mengajukan berbagai pertanyaan yang dapat mendorong siswa untuk dapat merumuskan jawaban sementara atau dapat merumuskan berbagai perkiraan kemungkinan jawaban dari suatu permasalahan yang dikaji. Perkiraan sebagai hipotesis bukan sembarang perkiraan, tetapi harus memiliki landasan berpikir yang kokoh, sehingga hipotesis yang dimunculkan itu bersifat rasional dan logis. Kemampuan berpikir logis itu sendiri akan sangat berpengaruh oleh kedalaman wawasan yang dimiliki serta keluasan pengalaman. Dengan demikian, setiap individu yang kurang mempunyai wawasan akan sulit mengembangkan hipotesis yang rasional dan logis.

Keterampilan proses siswa lainnya yang mengalami peningkatan adalah merumuskan prosedur kerja. Merumuskan prosedur kerja atau merancang sebuah pengamatan dalam pembelajaran inkuiri terbimbing dimana siswa diberikan kesempatan oleh guru untuk menentukan langkah-langkah yang sesuai dengan hipotesis yang dilakukan, dalam hal ini siswa mengurutkan langkah-langkah atau prosedur kerja dalam melakukan pengamatan yang akan dilaksanakan.

Menurut Dimyati dan Mudjiono (2006) agar suatu penelitian dapat 
dilaksanakan secara baik dan menghasilkan sesuatu yang berguna dan bermakna, maka diperlukan adanya rancangan penelitian. Keterampilan merumuskan prosedur kerja atau merancang pengamatan perlu diberikan pada siswa, sehingga melalui pembelajaran inkuiri anak terlatih untuk merancang dan melakukan penyelidikan melalui pengamatan ke lingkungan alami seperti di ekosistem sawah. Hal ini bertujuan agar dengan melatih siswa merumuskan prosedur kerja atau merancang suatu penelitian untuk dapat melaksanakan penelitian dengan baik dan dapat menghasilkan sesuatu yang bermanfaat.

Pengamatan merupakan kemampuan yang meliputi kemampuan mengideintifikasi fenomena objek tertentu, dan mengidentifikasi persamaan dan perbedaan objek tertentu dengan alat inderanya secara teliti. Menurut Dimyati dan Mudjiono (2006) melalui pengamatan, siswa belajar tentang dunia nyata yang dapat menuntut keingintahuan, mempertanyakan, memikirkan, melakukan interpretasi tentang lingkungan kita, dan meneliti lebih lanjut. Selain itu, kemampuan mengamati merupakan keterampilan paling dasar dalam proses dan memperoleh ilmu pengetahuan serta merupakan hal terpenting untuk mengembangkan keterampilan-keterampilan proses yang lain.

Pembelajaran inkuiri yang dilakukan pada lingkungan alami siswa akan mengalami secara langsung proses penyelidikan dalam penelitian yang mereka lakukan. Melalui pengalaman maka pengetahuan dalam diri siswa akan tumbuh dan berkembang, hal ini akan terwujud apabila siswa dilatih dan terus dilatih dengan model pembelajaran inkuiri terbimbing berbasis lingkungan. Karena pemahaman siswa akan semakin kuat dan melekat pada dirinya apabila selalu diuji dengan pengalaman-pengalaman yang baru dan menantang untuk diselidiki oleh siswa.

Keterampilan proses siswa dalam menganalisis hasil pengamatan belum dapat ditingkatkan. Hal ini dikarenakan siswa belum terbiasa dengan kegiatan pembelajaran tersebut, sehingga mereka kurang terlatih dalam keterampilan menganalisis hasil pengamatan. Selain itu, di duga karena proses pembelajaran oleh guru sehari-hari belum mengarah pada keterampilan menganalisis hasil pengamatan, sehingga ketika siswa dihadapkan dengan penilaian menganalisis hasil pengamatan siswa mengalami kesulitan. Keterampilan siswa dalam menganalisis hasil pengamatan merupakan kemampuan belajar memecahkan masalah. Menurut Kunandar (2009) siswa belajar memecahkan masalah secara mandiri dan memiliki keterampilan berpikir kritis karena mereka harus selalu menganalisis dan menangani informasi.

Pembelajaran inkuiri dapat melatih dan mengukur kemampuan siswa dalam keterampilan menganalisis hasil penyelidikan yang mereka temukan. Sehingga akan menjadikan siswa sebagai calon ilmuwan yang andal dalam melaksanakan penyelidikan dengan baik. Jika siswa masih belum terampil dalam menganalisis hasil, maka guru perlu melatih dan terus melatih kemampuan siswa dalam keterampilan berpikir untuk memaknai setiap proses pembelajaran. Salah satu pendekatan dalam pembelajaran yang dapat melatih kemampuan siswa dalam menganalisis data adalah melalui pembelajaran inkuiri. Sehingga siswa dapat belajar memecahkan masalah secara mandiri dan memupuk keterampilanketerampilan berpikirnya, karena mereka 
harus menganalisis dan memanipulasi informasi yang mereka temukan sendiri.

Keterampilan proses siswa dalam merumuskan kesimpulan juga belum dapat ditingkatkan Hal ini melatih siswa agar lebih terampil dan lebih baik lagi dalam melaksanakan suatu penelitian bukan masalah yang mudah dipecahkan, karena tergolong keterampilan proses tingkst tinggi. Selama ini hasil proses pembelajaran tidak begitu diperhatikan, sehingga guru tidak begitu tahu bagaimana kemampuan siswa dalam keterampilan proses belajar, terutama dalam membuat kesimpulan dengan baik dan benar sesuai hasil pengamatan yang mereka peroleh.

Menurut Dimyati dan Mudjiono (2006) menyimpulkan dapat diartikan sebagai suatu keterampilan untuk memutuskan keadaan suatu objek atau peristiwa berdasarkan fakta, konsep, dan prinsip yang diketahui. Kesimpulan dibuat berdasarkan hasil pengamatan dan hasil analisis pengamatan. Jadi, pembelajaran inkuiri terbimbing merupakan pembelajaran yang akan mengarahkan siswa untuk mendapatkan suatu kesimpulan dari serangkaian aktivitas yang dilakukan sehingga siswa seolah-olah menemukan sendiri pengetahuan tersebut.

Hasil penelitian ini sejalan dengan penelitian sebelumnya (Kubicek, 2005; Rozi, 2010). Berdasarkan hasil penelitian yang dilakukan oleh Kubicek (2005) bahwa pembelajaran berbasis inkuiri dapat meningkatkan pemahaman siswa dengan melibatkan siswa dalam proses kegiatan pembelajaran secara aktif, sehingga konsep yang dicapai lebih baik. Penelitian yang senada yang dilakukan oleh Rozi (2010) bahwa kemampuan kerja ilmiah dengan strategi inkuiri terbimbing lebih tinggi daripada dengan strategi inkuiri terstruktur.

Menurut Eggen \& Kauchak (1996) salah satu ciri pembelajaran yang efektif, adalah apabila siswa menjadi pengkaji yang aktif terhadap lingkungannya melalui mengobservasi, membandingkan, menemukan kesamaan-kesamaan dan perbedaan-perbedaan serta membentuk konsep dan generalisasi berdasarkan kesamaan-kesamaan yang ditemukan. Sebaliknya jika keefektifan pembelajaran belum maksimal dapat diasumsikan karena siswa belum terbiasa dan terlatih dalam menemukan konsep-konsep tersebut secara mandiri. Siswa terbiasa dengan pembelajaran konvensional yang mengakibatkan siswa menjadi pasif.

Peningkatan keterampilan proses siswa dalam kegiatan inkuiri terbimbing yang dirancang juga sejalan dengan pemilihan konsep ekosistem yang dilaksanakan pada lingkungan alami. Pada konsep ekosistem ini di dalamnya sarat dengan kemampuan melakukan keterampilan proses melalui penyelidikan dengan melakukan pengamatan terhadap lingkungan sekitar sekolah seperti ekosistem sawah. Peneliti menemukan adanya keterlibatan siswa secara aktif dalam proses pembelajaran untuk menemukan konsep ekosistem yang sedang mereka pelajari yang langsung dilaksanakan di lingkungan nyata. Dengan demikian pemilihan konsep ekosistem ini sudah sesuai dengan menggunakan pendekatan inkuiri terbimbing berbasis lingkungan untuk meningkatkan kreativitas siswa dalam proses pembelajaran.

Pembelajaran inkuiri terbimbing dapat digunakan dengan baik pada siswa SMAN 4 Barabai dengan melakukan proses penemuan dan mengalami proses mental yang lebih tinggi tingkatannya melalui keterampilan proses, seperti merumuskan prosedur kerja pengamatan, melakukan penyelidikan melalui pengamatan, menganalisis hasil pengamatan, dan membuat kesimpulan berdasarkan 
pengamatan secara langsung pada lingkungan di sekitar mereka seperti pada ekosistem sawah. Dengan demikian, pembelajaran inkuiri dapat menata lingkungan/suasana belajar yang berpusat pada siswa dengan memberikan bimbingan secukupnya dalam menemukan konsepkonsep dan prinsip-prinsip ilmiah.

Inkuiri terbimbing merupakan model pembelajaran yang cocok digunakan dalam menemukan konsep-konsep secara mandiri dengan baik, sehingga pembelajaran lebih efektif dan lebih bermakna. Jadi, siswa SMA Negeri 4 Barabai dengan pembelajaran berbasis inkuiri terbimbing akan melatih siswa dalam berpikir secara sistematis, logis, dan abstrak. Hal ini karena dalam proses pembelajaran siswa berperan secara aktif dan bersungguh-sungguh yang berdampak pada hasil belajar yang baik.

Pembelajaran inkuiri terbimbing pada konsep ekosistem menggunakan pendekatan lingkungan. Hal ini sejalan dengan penelitian Ristanto (2010) menjelaskan terdapat perbedaan pengaruh pembelajaran berbasis inkuiri terbimbing dengan multimedia dan lingkungan riil terhadap prestasi belajar biologi materi pokok ekosistem. Sedangkan pada penelitian Dwindiansih (2011) menjelaskan bahwa pendekatan lingkungan berpengaruh terhadap hasil belajar siswa SMAN 3 Banjarbaru.

Implementasi pembelajaran inkuiri tidaklah semudah yang dibayangkan, namun dalam penerapannya terdapat berbagai kesulitan. Menurut Sanjaya (2008) pembelajaran inkuiri menekankan kepada proses berpikir yang bersandarkan pada proses belajar dan hasil belajar. Selama ini guru yang sudah terbiasa dengan pola pembelajaran sebagai proses menyampaikan informasi yang lebih menekankan kepada hasil belajar, banyak yang merasa keberatan untuk mengubah pola mengajarnya. Selain itu, pembelajaran inkuiri sulit mengontrol kegiatan dan keberhasilan siswa, sulit dalam merencanakan pembelajaran oleh karena terbentur dengan kebiasaan siswa dalam belajar, serta memerlukan waktu yang panjang sehingga sering guru sulit menyesuaikannya dengan waktu yang telah ditentukan.

Dalam pembelajaran dengan pendekatan inkuiri ini siswa akan dihadapkan pada suatu permasalahan yang harus diamati, dipelajari, dan dicermati, yang pada akhirnya dapat meningkatkan pemahaman konsep dalam kegiatan pembelajaran. Secara logika apabila siswa meningkat partisipasinya dalam kegiatan pembelajaran, maka secara otomatis akan meningkatkan pemahaman konsep materi pembelajaran, dan pada akhirnya akan dapat meningkatkan prestasi belajar.

Namun pendekatan inkuiri memiliki keunggulan dari pendekatan pembelajaran yang lain, salah satu keunggulannya yaitu memberikan ruang kepada siswa untuk belajar sesuai dengan gaya belajar mereka, serta dapat melayani kebutuhan siswa yang memiliki kemampuan di atas rata-rata. Pembelajaran inkuiri dianggap sesuai dengan perkembangan psikologi belajar modern yang menganggap belajar adalah proses perubahan tingkah laku berkat adanya pengalaman.

\section{SIMPULAN}

Penerapan model inkuiri terbimbing dapat meningkatkan keterampilan proses merumuskan masalah atau pertanyaan, merumuskan hipotesis atau jawaban sementara, merumuskan prosedur kerja dalam melakukan pengamatan dan melakukan penyelidikan 
melalui pengamatan. Sebaliknya menganalisis hasil pengamatan dan membuat kesimpulan belum berhasil ditingkatkan.

\section{DAFTAR PUSTAKA}

Borich, G.O., 1994. Observasional Skill for Effective Teaching, New York: Macmillan Publishing Company.

Bryce, T.G.K., McCall, J., MacGregor, J., Robertson, I.J., \& Weston, R.A.J. 1990. Techniques for assessing process skills in practical science: Teacher's guide. Oxford: Heinemann Educational Books.

Dimyati dan Mudjiono. 2006. Belajar dan Pembelajaran. Jakarta: Pusat Perbukuan \& Rineka Cipta.

Dwindiansih, W. 2011. Pemahamana Konsep Keanekaragaman Hayati dan Etika Lingkungan Siswa SMAN 3 Banjarbaru Melalui Pendekatan Lingkungan. Tesis. Program Pasca Sarjana Magister Pendidikan Biologi. Unlam. Banjarmasin. Tidak diterbitkan.

Eggen, Paul D. dan Donald P. Kauchak. 1996. Strategies and Models for Teachers: Teaching Content and Thinking Skills. 6th ed. Boston: Pearson Education, Inc.,publishing as Allyn \& Bacon, 501 Boylston Street, MA,02116.

Hamalik, Oemar. 2004. Proses Belajar Mengajar. Bumi Aksara. Jakarta.

Hidayat, Wahyu. 2005. Abstrak Thesis 2005 Program Studi Pendidikan Ilmu Pengetahuan Alam. Pendekatan Pembelajaran Guide Inquiry dengan Kegiatan Laboratorium pada Pokok Bahasan Koloid. (http://pagesyourfavorite.com/ppsupi/abstrakipa 2005.html. Diakses 10 Februari 2016).
Kariani, Taviv Listin. 2015. Meningkatkan Aktivitas dan Hasil Belajar IPA Materi Benda Langit dan Peristiwa Alam dengan Metode Demonstrasi pada Siswa Kelas I SDN Ampel 04 Wuluhan Jember. Pancaran, 4 (4), 125-136, Nopember 2015. jurnal. unej.ac.id/ index.php/pancaran/ article/download/2184 /1778 diakses tanggal 4 Maret 2016. 